\section{Civil Code}

According to Article 128 of the Greek Civil Code, all adults (i.e. those aged over 18 years) are considered legally responsible (e.g. are able to sign legal documents). A person arguing that someone is incapacitous has to prove the incapacity and not vice versa. Articles 129 and 130 clarify the concept of diminished capacity. Individuals may have the right to decide some of their own affairs under certain circumstances. The ability of someone to make a will is closely connected with the above (Androulakis, 1986).

\section{Legislation on substance misuse and offending behaviour}

The current legislation on substance misuse (Law 3459/2006, called the Code of Laws on Narcotics) introduced the concept of 'decriminalisation' for individuals dependent on illegal substances. This legislative reform aims to encourage treatment initiation and reduce prison sentences for individuals with addictions (mainly heroin addiction) who commit petty offences (Kotsalis et al, 2007).

If a court accepts that defendants are addicted, then they can receive a reduced sentence, as indicated above for persons with a mental illness. Defendants making such a claim as part of their defence have to be examined by a psychiatrist and receive a psychiatric report confirming the presence or absence of addiction (according to the DSM-IV-TR criteria). This can be difficult to achieve since the psychiatrist is not called immediately after the arrest.

\section{Discussion}

Although in theory the law safeguards human rights, in practice a lack of resources makes its application problematic. For instance, the ombudsman (a citizens' advocate for civil rights) in Greece, in a special report published in 2007, indicated that mental health professionals are not acting according to the legal prerequisites (Department of Health and Social Welfare, 2007). The medical reports often contain no clear record of an assessment of a patient's ability to decide on healthcare and the stock phrase the prerequisites for law 2071 are met' is often used. Additionally, it was not certain that patients were being properly informed about their right of legal appeal. More disturbingly, though, the ombudsman discovered that no court decision was recorded for $84 \%$ of the cases of involuntary admission and that for the majority of cases the rule that there should be a maximum 10-day wait for a court decision had not been met. These findings indicate that the legal system is treating involuntary admissions without due process. New ways of approaching the right of appeal, including the 'Greek equivalent' of mental health review tribunals, have been suggested by the Greek Forensic Psychiatry Association. It is more than 20 years since the introduction of Law 2071, and it now needs to be updated and redrafted.

\section{References}

Androulakis, M. (1986) Penal Code. General Part (vol. 3) [in Greek]. Sakkoulas Publications.

Department of Health and Social Welfare (2007) Special Report: Own-Initiative Investigation by the Ombudsman into the Involuntary Hospitalisation of Mentally III Patients. Department of Health and Welfare. Summary available at http://www.synigoros. $\mathrm{gr} /$ ? i=health-and-social-welfare.en.recentinterventions. 35018 (accessed December 2013).

Douzenis, A. \& Lykouras, L. (eds) (2008) Forensic Psychiatry [in Greek]. Paschalides Publications.

Douzenis, A., Michopoulos, I., Economou, M., et al (2012) Involuntary admission in Greece: a prospective national study of police involvement and client characteristics affecting emergency assessment. International Journal of Social Psychiatry, 58, 172-177.

Douzenis, A., Michopoulos, I., Gournellis, R., et al (2013) Differences between elderly voluntary and involuntary admitted patients in Greece. International Psychogeriatrics, 25, 25-33.

Kotsalis, L., Margaritis, M. \& Farsedakis, I. (2007) Legislation on Narcotics. Explanatory Comments of Law 3459/2006 on Narcotics [in Greek]. Sakkoulas Publications.
MENTAL HEALTHLAW PROFILE

\title{
Mental health law in Turkey: legislation pending
}

\author{
Esra Caglar ${ }^{1}$ MD MRCPsych and Muzaffer Kaser ${ }^{2}$ MD MPhil
}

${ }^{1}$ Consultant Child and Adolescent Psychiatrist, London, UK, email esra@caglar.com

${ }^{2}$ Psychiatrist, PhD Candidate at the Department of Psychiatry, University of Cambridge, Visiting Lecturer at Bahcesehir University, Istanbul, Turkey
In Turkey, mental health professionals, together with patients and carers, have been involved in the drafting of the Mental Health Bill which is presently under consideration by Parliament. While the Mental Health Law is pending, various pieces of legislation are being used for different types of involuntary admission. The prospective Mental Health Law is of paramount importance for doctors, patients and families.
The Mental Health Law in Turkey is still at the proposal stage and has not yet been enacted (Psychiatric Association of Turkey, 2007). This has significant repercussions. Various groups, including clinicians, patients and carers, are affected and take on major responsibilities to compensate for the lack of specific mental health legislation. Currently, clinical practice is heavily influenced by cultural factors, such as carers' attitudes towards people who are mentally ill and the family's 
resources. However, there is nonetheless a legal framework to compensate for the lack of specific mental health legislation. The Ministry of Health (2011) has a mental health action plan that prioritises finalisation of the Mental Health Law. The proposal is still pending discussion in Parliament.

Turkey has a long history of providing mental health treatment in in-patient settings. As early as 500 years ago, at the time of the Ottoman Empire, mental illness was recognised as a physical ailment and physicians treated patients in therapeutic settings using holistic approaches that included music therapy. Several mental health institutions were established in the early 19th century. The first regional psychiatric state hospital was set up after the foundation of the Republic of Turkey in 1923. Currently, university, state, military and private hospitals provide in-patient psychiatric treatment.

In Turkey, family members are the main providers of care and are usually the legal guardians of patients with mental illness. Most people with severe mental illnesses live with their families and the number of homeless patients with schizophrenia is lower in Turkey than in other European countries. On the other hand, family-related factors have a large influence on the course of treatment and admission rates of patients with schizophrenia in Turkey. Thus, patients from families who are less functional are likely to be admitted more often (Taktak et al, 2000).

\section{The proposed Mental Health Law}

The Psychiatric Association of Turkey began work on draft legislation in 1998 and the first proposal was released in 2006, after a specialist task force was appointed (Psychiatric Association of Turkey, 2007). The task force had representation from 15 professional organisations, including the Psychiatric Association of Turkey, the Turkish Medical Association and numerous charities formed by patients and carers. The proposed Bill supports not only patients' rights to treatment but also clinical governance in mental health settings. The Bill defines voluntary and involuntary admissions, how an independent psychiatrist is to be involved in decision-making, how the courts should be informed of long-term involuntary admissions and patient care after discharge. It has been regarded as an unusual but valuable opportunity that a new law is being created afresh (Arikan et al, 2007).

\section{Current practice}

In current practice, the family should consent to the involuntary admission if the patient lacks capacity at the time of assessment. This also means that the family can either refuse admission or discharge the patient by withdrawing consent, against medical advice. This system places clinicians, patients, carers and the general public in a vulnerable position. The question of whose responsibility it is when things go wrong is an important one. There are examples, albeit few, of unfavourable and at times tragic results. Patients can be left untreated. Clinicians also suffer from not being able to provide optimum treatment and the carers have to take on overwhelming responsibilities.

While specific legislation for involuntary admissions is still lacking, psychiatric units are making use of an article in the Turkish Civil Code (Ministry of Health, 2011). Article 432 sets out the requirements for involuntary admission: the patient must have a mental illness and pose a danger to the public. The same article covers infectious diseases, intellectual disability and alcohol or drug misuse or vagrancy. It further states that patients should be discharged as soon as they are fit. The article has not been prepared for or tailored to the needs of people who are mentally ill, their well-being or rights; rather, the focus is on the 'safety of the public' (Sercan, 2007).

Until 2008, Article 432 had been rarely used by the legal authorities or mental health professionals. Since then, with the support of the Mental Health Law initiatives taken by the Psychiatric Association of Turkey and also with the support of several clinical directors of psychiatric state hospitals who contacted their local courts, this piece of legislation began to be used within routine clinical practice. Currently, psychiatric state hospitals and most of the university hospitals use Article 432. If the judge decides that a patient meets the criteria set out in the Civil Code, then permission is given and Article 432 is used for involunatry admission. However, there are still ongoing difficulties, such as delays in court decisions, problems with the appeal procedure and communication problems with regard to discharge. Although the active use of Article 432 in psychiatric practice has effectively established a legal framework and thereby reduced the uncertainties for psychiatrists, patients and carers, it can be regarded only as a subsidiary regulation until the Mental Health Law is passed.

Other forms of involuntary admission, particularly for patients who are involved in criminal acts, are regulated by the Turkish Criminal Law. The Criminal Court can decide on a compulsory admission of a patient who has a history of offending. This is only for up to 3 weeks, as part of an assessment process of criminal responsibility (Criminal Procedure Law, Article 74). If the forensic psychiatric assessment concludes that the patient does not have criminal responsibility due to a mental illness, the patient does not receive a conviction and is instead compulsorily admitted to a psychiatric ward. The relevant article of the Turkish Criminal Law (Article 57) also defines discharge processes and the frequency and the reporting of compulsory follow-up visits following discharge (Sercan, 2007). The Mental Health Law is expected to be compliant with the relevant articles of Turkish Criminal Law, although further amendments might be required when the Mental Health Law is debated in Parliament (Psychiatric Association of Turkey, 2007).

Consent should be obtained from parents for 
the admission of anyone under 18 years of age. When there are no parents involved in the care of the child, as in the case of children living in children's homes or foster homes, social services have legal responsibility and should give consent. Under the Child Protection Law, a child is entitled to safeguarding, to receive healthcare, to adequate shelter and to an education. This law is used in the best interests of the child to enable the child to receive adequate treatment, including in-patient and out-patient psychiatric care when necessary.

Turkey provides an example of how different pieces of legislations can be used for involuntary admissions while the proposed Mental Health Law is pending discussion in Parliament. In the meantime, mental health professionals in conjunction with patients and carers continue to campaign for the Mental Health Law.

\section{References}

Arikan, R., Appelbaum, P. S., Sercan, M., et al (2007) Civil commitment in Turkey: reflections on a bill drafted by psychiatrists. International Journal of Law and Psychiatry, 30, 29-35.

Ministry of Health (2011) Mental Health Action Plan [in Turkish], at http://www.saglik.gov.tr/TR/dosya/1-73168/h/ulusal-ruh-sagligieylem-plani.pdf (accessed December 2013).

Psychiatric Association of Turkey (2007) Mental Health Law proposal [in Turkish], at http://www.psikiyatri.org.tr/uploadFiles/ TPD_RUH-SAGLIGI_YASA_TASARISI_TASLAGI_2007_05_01_2007. doc (accessed December 2013)

Psychiatric Association of Turkey (2008) Press release [in Turkish], at http://www.psikiyatri.org.tr/presses.aspx?press $=269 \&$ type $=24$ (accessed December 2013).

Sercan, M. (ed.) (2007) Adli Psikiyatri Uygulama Kılavuzu [Forensic Psychiatric Practice Guide]. Dizisi 5. Türkiye Psikiyatri Derneği Bilimsel Çalışma Birimleri.

Taktak, S., Erkiran, M., Karsidag, C., et al (2000) Sizofren olgularda aile islevselliginin algilanmasi, sosyodemografik ve klinik ozelliklerle iliskisi uzerine bir calisma [Perception of family functioning in schizophrenic patients, sociodemographic and clinical features, with a working relationship]. Dusunen Adam, 13, 196-203.

\section{4-27 June,}

Barbican Centre, London

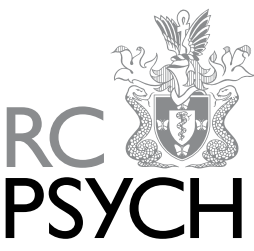

\section{Royal College of Psychiatrists'}

\section{International Congress 2014}

\section{PSYCHIATRY: THE HEARTLAND OF MEDICINE}

in he International Congress provides overviews, workshops and training on important areas in the science, policy and practice of Psychiatry. Keynote lectures from world renowned speakers, a dedicated stream for trainees and stand alone symposia will focus on topics including: treatment, clinical skills, neurology, new science, communications \& technology, management \& leadership and teaching. There will also be a poster and oral presentation competition

\section{Contact email: congress@rcpsych.ac.uk}

Programme and registration form available on www.rcpsych.ac.uk/congress 